\title{
Diversity and determinants of corporate financing decisions: survey evidence
}

\author{
Vivien Beattie, Alan Goodacre ${ }^{*}$ and Sarah Jane Thomson
}

March 2004

\begin{abstract}
Despite theoretical developments in recent years, our understanding of corporate capital structure remains incomplete. Prior empirical research has been dominated by archival regression studies which are limited in their ability to fully reflect the diversity found in practice. The present paper reports on a comprehensive survey of corporate financing decision-making in 192 UK listed companies.

A key finding is that firms are heterogeneous in their capital structure policies. About half of the firms seek to maintain a target debt level, consistent with trade-off theory, but $60 \%$ claim to follow a financing hierarchy, consistent with pecking order theory. These two theories are not viewed by respondents as either mutually exclusive or exhaustive, since some firms adopt (at least partially) both strategies, while a significant number of firms do not appear to follow either of these strategies. Such observations raise concerns about the usefulness of large-scale regression modelling of capital structure determinants. In normal usage, these models can only describe whether a particular theory is consistent with the observed capital structure of the 'average firm' in the population. They are not typically used to model the diversity of capital structure practice.
\end{abstract}

As found in many regression-based determinant studies, there is clear evidence here that company size affects corporate financing decisions. For example, large companies are more likely to adopt a target debt level and to maintain financial slack (though not more likely to follow a hierarchy of finance). Similarly, current high levels of gearing encourage a greater focus on particular issues such as projected cash flows, loan covenants and non-interest tax shields. This contingency on debt levels suggests that empirical studies of capital structure dynamics may be particularly fruitful.

Investigation of debt level determinants shows that many of the theoretical arguments are widely accepted by respondents, in particular the importance of interest tax shield, financial distress, agency costs and also, at least implicitly, information asymmetry.

Keywords: Capital structure; survey; trade-off theory; pecking order theory; agency theory.

JEL: G32

\footnotetext{
* The authors are, respectively, Professor of Accounting (University of Glasgow), Professor of Accounting and Finance (University of Stirling) and Lecturer (Heriot-Watt University). The financial support of the Centre for Business Performance of the Institute of Chartered Accountants in England and Wales and of the Carnegie Educational Trust (for Sarah Jane Thomson) is gratefully acknowledged. The contribution made by the individuals who gave freely of their time in completing the questionnaire is also greatly appreciated.
}

Address for correspondence: Alan Goodacre, Department of Accounting, Finance and Law, University of Stirling, Stirling FK9 4LA, UK (e-mail: Alan.Goodacre@stir.ac.uk). 


\section{Diversity and determinants of corporate financing decisions: survey evidence}

\section{INTRODUCTION}

Since the seminal publication of Modigliani and Miller (1958), corporate finance researchers have devoted considerable effort to investigating capital structure decisions (e.g. Myers, 1977, 1984). Significant progress has been made in understanding the determinants of corporate capital structure with an increased emphasis on financial contracting theory (see, for example, Barclay and Smith, 1995; Mehran et al., 1999; Graham et al., 1998 and, for an international view, Rajan and Zingales, 1995). This theory suggests that firm characteristics such as business risk and investment opportunity set affect contracting costs. In turn, these costs impact on the choice between alternative forms of finance such as debt and equity, and between different classes of fixed-claim finance such as debt and leasing. Recent studies have begun to focus on dynamic aspects of capital structure (Ozkan, 2001; Antoniou et al., 2002; Baker and Wurgler, 2002; Welch, 2004; Leary and Roberts, 2003; Flannery and Rangan, 2003). However, our understanding remains incomplete and this has prompted a large number of recent studies in the area of capital structure.

The approach adopted in most studies seeks to explain observed capital structures in terms of factors felt likely to be important, usually using large-scale cross-sectional (and time series) regression methods. This approach involves identification of the broad consensus (average) behaviour of firms. It cannot capture the diversity in behaviour that can arise from firms adopting different capital structure policies, and which would lead to different functional forms in the regression models. Further, even in dynamic time series studies, only indirect inferences can be made about the financing decisionmaking process as only the outcome of the process is studied. Writers in the area are beginning to argue that it is necessary to augment the dominant archival method by the use of different empirical approaches that offer greater insight into the behavioural aspects of the decision process (Tufano, 2001). ${ }^{1}$ Survey methods and clinical methods are both candidates in this regard.

The main aim of the present paper is to report on a comprehensive survey of the corporate financing decision-making process in UK companies to, inter alia, enable a comparison between practice and extant theories of capital structure. This requires knowledge of the measures that managers use, the factors that affect the choices made, and the theories that are being applied (either explicitly or implicitly, partially or completely) as well as knowledge of those factors and theories that they apparently disregard. Thus, the objective is to understand how companies determine their overall financing strategy, why they choose a particular mix of financing instruments, and why they choose to limit borrowings or set up spare borrowing capacity. The method explicitly allows a description of the diversity of capital structure practice. This then opens up the possibility for future research to investigate the specific factors or characteristics that encourage firms to choose different financing policies.

One of the key findings of the study is that firms are heterogeneous in their capital structure policies. About half of the firms seek to maintain a target debt level, consistent with trade-off theory. However, $60 \%$ of responding firms argued that they follow a financing hierarchy, consistent with pecking order theory. These two theories were not viewed by respondents as either mutually exclusive or exhaustive. Such observations raise doubts about the usefulness of adopting large-scale archival methods to investigate capital structure determinants since they cannot, in standard form, describe such diversity.

The remainder of the paper is structured as follows. Section two provides a review of relevant theoretical and empirical literature and section three outlines the sample and data collection procedures employed. The results are presented in section four, followed by a summary and discussion in section five and a conclusion. 


\section{LITERATURE}

The capital structure literature is extensive and only a brief selective summary is provided below. For a more comprehensive treatment see the major review by Harris and Raviv (1991).

\section{(i) Capital structure: theory}

A basic model of capital structure determination has derived from the with-taxes Modigliani and Miller $(1958,1963)$ model with expansion to incorporate the financial distress costs of debt. This traditional static trade-off theory can be characterised by the assumption that capital structure is optimised with management weighing up the relative advantage of the tax-shield benefits of debt against the increased likelihood of incurring debt-related bankruptcy costs (Myers, 1984).

However, in seeking to model the wide diversity of capital structure practice, a number of additional factors have been proposed in the literature. First, the use of debt finance can reduce agency costs between managers and shareholders by increasing the managers' share of equity (Jensen and Meckling, 1976) and by reducing the 'free' cash available for managers' personal benefits (Jensen, 1986). It may also encourage managers to perform better in order to reduce the likelihood of bankruptcy, which is costly for managers (Grossman and Hart, 1982). Conflicts between debtproviders and shareholders arise because the debt contract gives shareholders an incentive to invest sub-optimally in very risky projects. This implies an agency cost of using debt finance. Jensen and Meckling (1976) argue that an optimal capital structure can be obtained by trading off the agency costs of debt against the benefit of debt, in what might be termed an extended trade-off model.

Second, Myers and Majluf (1984) argue that, under asymmetric information, equity may be mispriced by the market. If firms finance new projects by issuing equity, underpricing may be so severe that new investors gain more of the project NPV to the detriment of existing shareholders. This may lead to an 'underinvestment' problem since such projects will be rejected even if the NPV is positive. This underinvestment can be reduced by financing the project using a security that is less likely to be mispriced by the market. Internal funds involve no undervaluation and even debt that is not too risky will be preferred to equity. Myers (1984) refers to this as the pecking order theory of capital structure. The description follows earlier empirical work by Donaldson (1961), in which he observed that managers preferred to fund investment initially from retained profits rather than use outside funds. This preference led firms to adopt dividend policies that reflected their anticipated need for investment funds, policies which managers were reluctant to substantially change. If retained profits exceeded investment needs then debt would be repaid. If external finance was required, firms tended first to issue the safest security, debt, and only issued equity as a last resort.

Under this model, there is no well-defined target mix of debt and equity finance. Each firm's observed debt ratio reflects its cumulative requirements for external finance. Generally, profitable firms will borrow less because they can rely on internal funds. The preference for internal equity implies that firms will use less debt than suggested by the trade-off theory. Further, firms are more likely to create financial slack to finance future projects.

Other factors that have been invoked to help explain the diversity of observed capital structures include: management behaviour (Williamson, 1988); corporate strategy (Barton and Gordon, 1988); firm-stakeholder interaction (Grinblatt and Titman, 1998, Ch. 16); and corporate control issues (Harris and Raviv, 1988, 1991).

A significant strand of the empirical literature has sought to distinguish which of the two main theories best explains capital structure practice (e.g. Shyam-Sunder and Myers, 1999; Fama and French, 2002; Adedeji, 2002; Frank and Goyal, 2003). Implicit in such testing is that the theories have elements that are mutually exclusive. While the theories in their basic form do lead to a set of 'precisely opposite' predictions (Barclay and Smith, 1999), there is increasing recognition that neither theory is able, independently, to explain the complexity encountered in practice. This is particularly 
true when seeking a unified theory to explain the broader array of corporate financial policy choices (Barclay and Smith, 1999).

\section{(ii) Capital structure: empirical evidence}

In the main, two empirical approaches have been used to obtain evidence on factors that affect corporate financing decisions. The first approach, adopted in the majority of studies, seeks to explain observed capital structures in terms of factors felt likely to be important, usually using cross-sectional regression methods. Based on an informal meta-analysis of twenty papers across several countries, Thomson (2003) identifies several key features of firms that seem to be related to debt ratios across a wide range of environments and through time: size $(+)$, earnings variability $(+)$, asset tangibility $(+)$, profitability $(-)$, investment opportunity set $(-)$ and industry. The evidence on tax influence is weak, perhaps reflecting the endogeneity between tax rates and financing choice (Graham et al., 1998). With a few exceptions, UK cross-sectional studies (Bennett and Donnelly, 1993; Lasfer, 1995; Adedeji, 1998; Bevan and Danbolt, 1998) and panel regression studies (Ozkan, 2001; Antoniou et al., 2002; Bevan and Danbolt; 2004) generally find similar relationships to those found in the US and elsewhere. Two of the robust observations cause specific difficulties for theory: the negative relationship between debt ratio and profitability is consistent with the logic of pecking order theory but inconsistent with trade-off theory; the negative investment opportunity set observation supports trade-off theory but not pecking order theory.

Other UK studies include an early one by Marsh (1982), who investigated security issues and found that companies are heavily influenced by market conditions and the past history of security prices in choosing between debt and equity. He also provided evidence that companies appear to make their choice of financing instruments as if they have target levels of debt in mind. These debt levels are themselves functions of company size, bankruptcy risk and asset composition. The related study by Walsh and Ryan (1997) found both agency and tax considerations were important in determining debt and equity issues. Lasfer (1999) investigated the determinants of debt structure, maturity and priority structures and found significant differences across company size; in particular, the relationship between debt and agency costs only applies to large companies whereas small company debt appears to be driven by profitability. Bevan and Danbolt (2002) focused on the difficulties in measuring gearing and found that debt determinants appear to vary significantly between short-term and longterm components of debt. The pecking order theory prediction that there should be a negative relationship between the dividend payout ratio and investment was confirmed by Adedeji (1998). In a UK replication and extension of the Shyam-Sunder and Myers (1999) test of pecking order against trade-off theory, Adedeji (2002) found mixed evidence, with neither theory dominant. Overall, the evidence for the UK (as for the US) is somewhat inconclusive. While various individual factors can be identified as important, neither of the two major theories is capable independently of adequately explaining the outcomes of firms' financing decisions in practice.

Recent studies have begun to focus on dynamic aspects of capital structure such as whether, as implied in the trade-off theory, firms engage in capital structure rebalancing. Ozkan (2001) provided evidence that UK firms do have target ratios and adjust to the target ratio relatively quickly. Antoniou et al. (2002) showed that firms in three European countries (including the UK) adjust their debt ratios to attain target structures, but at different speeds, suggesting that environmental and traditions are also important determinants. Baker and Wurgler (2002) and Welch (2004) suggested that US firms fail to rebalance in response to changes in leverage resulting from equity issues, or market changes in equity values, respectively. By contrast, Leary and Roberts (2003) argued that frictions in the capital markets encourage firms to adjust capital structure, but that this adjustment is relatively infrequent, leading to 'extended excursions away from their targets' (Myers, 1984). They found that US firms behave as if they follow a dynamic trade-off policy in which they actively rebalance leverage to stay within an optimal range. Flannery and Rangan (2003) extended this idea by developing a model that allowed firms' target capital structures to vary over time and for firms to adjust gradually towards the target. They confirmed that US firms operate with a target leverage ratio, and more than halve the distance to the target within two years. Finally, one of the major observations contrary to the trade-off theory, the strong inverse relationship between profitability and leverage has been shown to be reconcilable by consideration of mean reversion in earnings (Sarkar and Zapatero, 2003). While the evidence is far 
from conclusive, on balance it seems that some form of target or target range is employed by firms, consistent with the logic of trade-off theory.

However, using the large-scale regression approach invariably involves identification of the average behaviour of firms and does not measure its diversity. In particular, it does not allow for the possibility that some firms may choose to adopt a hierarchical 'pecking-order view' of finance while others, perhaps the majority, adopt a target capital structure. ${ }^{2}$ Further, its focus on the outcomes of the financing decision-making process necessarily limits our understanding of the process itself. An alternative approach is to ask company managers directly about their attitudes and behaviour regarding corporate financing using the survey method. This allows both the process and diversity of practice to be investigated, offering a richer understanding of practice.

Prior surveys of general capital structure issues have been mainly US-based (e.g. Donaldson, 1961; Scott and Johnson, 1982; Pinegar and Wilbricht, 1989; Norton, 1989; Graham and Harvey, 2001). To the best of our knowledge, there exists only one published study on Australia (Allen, 1991) and one on the UK (Fawthrop and Terry, 1975) as well as two cross-country comparisons (Stonehill et al., 1975; Allen, 1999). ${ }^{3}$ Table 1 provides a brief summary of the survey studies.

$<$ TABLE 1 about here $>$

In the only UK study, Fawthrop and Terry's (1975) primary focus was on the use of leasing finance but they also included a small number of questions concerning attitudes to debt. Almost all respondents acknowledged that they would use debt to finance capital expenditure but that there was a limit to the amount of debt a company ought to use. This limit was likely to be set in relation to the debt to equity ratio or 'prior charges cover'. The size of this limit was not explicitly explored in the survey but a gearing limit of $40 \%$ was 'often' mentioned, without justification, in interview discussions. Unfortunately, the relatively early stage of theory development and the many environmental changes since 1974 severely limit the relevance of the results for current use.

More recently, Graham and Harvey (2001) conducted a major survey in the US of views about the cost of capital, capital budgeting and capital structure. The responses relating to capital structure suggest that firms are concerned about financial flexibility and credit ratings when issuing debt, and earnings per share dilution and recent stock price appreciation when issuing equity. They found some evidence to support both the pecking order theory and trade-off theory but little evidence that executives are concerned about asset substitution, asymmetric information, transaction costs, free cash flows, or personal taxes.

Survey-based analysis complements both the more common research method based on large sample regressions and intensive small-sample case studies. The use of multiple methods facilitates the triangulation of results. ${ }^{4}$ Our choice of survey approach in the current study reflects a desire to investigate the diversity of financial structure practice and aspects of the financing decision-making process itself rather than just the outcome of the process.

\section{METHODS}

\section{(i) Sample selection}

The sample of finance directors was based on the population of industrial and commercial UK listed companies contained in the UKQI list on Datastream in March 2000. The questionnaire was sent in July 2000 to a systematic sample of two-thirds (831) of this population. Non-response is a significant, and increasing, problem in the survey method and so a relatively large initial sample was used to provide a satisfactory absolute number of responses to support meaningful statistical analysis.

\section{(ii) Questionnaire design and administration procedures}

The questionnaire content was based upon a review of the theoretical and empirical literature in the area, including previous surveys. This was used to produce a draft questionnaire that was piloted on 
two finance directors (out of ten companies randomly selected from the non-sample balance of the population); a technical representative of the Association of Corporate Treasurers; and two professors of finance. The questionnaire content and terminology was revised accordingly.

The full questionnaire covering capital structure and leasing decisions was 16 pages long (including covers). It was accompanied by an explanatory covering letter that assured the confidentiality of responses. Each questionnaire was numbered to facilitate follow-up procedures and to enable the characteristics of responding companies to be identified. The contents page included general instructions for completion together with definitions of various key terms used in the questionnaire (capital structure, debt finance, equity finance and target capital structure). Seven pages were devoted to capital structure issues and asked for responses to a potential total of 98 question elements. ${ }^{5}$ Section A included questions relating to the determinants of the responding company's capital structure. Section B sought views on general statements regarding the determinants of capital structure. The final section asked for brief information about the respondent. The questionnaire used various question forms including those requiring yes/no answers, numerical estimates, ranking of alternatives, closed-form questions adopting a five-point Likert scale with verbal anchors and a small number of open-ended questions.

Many of the standard response-enhancing techniques were adopted including: designing a clear questionnaire layout; piloting; defining key terms at the start of the questionnaire; addressing the covering letter to a specific named individual (all finance director details and addresses were individually checked by telephone); covering letters signed individually by researchers; follow-up letters approximately 10 and 20 days after the initial request; stamped reply envelopes (rather than reply-paid envelopes); requesting non-respondents to return the questionnaire (Bourque and Fielder, 1995; Mangione, 1995).

\section{(iii) Further analysis procedures}

The extent to which respondents' opinions were related to company size, gearing level and industry group was also investigated. ${ }^{6}$ Several arguments link company size to capital structure decisions. First, large firms are typically more diversified and, therefore, less likely to suffer financial distress. Second, small firms are often restricted from using long-term debt and equity because of large fixed issuing costs, and tend to finance by short-term bank loans (Marsh, 1982). Third, small firms may be subject to greater agency costs because they are more flexible and better able to increase the risk of investment projects. Thus, lenders may be less willing to provide debt finance to small firms (Grinblatt and Titman, 1998).

These arguments suggest that, in general, large firms:

- have less concern than small firms about financial distress and agency costs of using debt;

- enjoy greater potential benefits from the debt tax shield, partly because distress/agency costs are lower and more directly because large firms are less likely to benefit from the 'small company' corporation tax rate of $20 \%{ }^{7}$

- have less concentrated managerial ownership suggesting:

- higher agency costs resulting from shareholder-manager conflict

- lower concern about corporate control issues than small firm owner-managers;

- have greater influence over their capital structure than small firms, as a result of transaction costs for market-based finance; thus, policies of maintaining a target debt level, or following a hierarchy, may be more sustainable for large firms; and

- have greater ability to maintain financial slack, given lenders reluctance to provide debt finance to small firms.

Respondents were classified into three equal-sized sub-samples of small, medium and large companies based on total assets, with comparisons being made between the responses from the large and small sub-samples. 
A firm's current level of gearing may influence a respondent's perception of the factors that are important in determining debt levels. For example, high geared firms might consider the interest tax shield benefit to debt and financial distress costs to be of great significance. Similarly, cash flows/income flows and restrictive covenants might be of greater concern. High gearing might encourage firms to seek to control debt by setting targets. They might have less opportunity to maintain financial slack if they are already functioning at or near their debt capacity. However, since firms with low debt capacity may also find financial slack hard to maintain, the relationship between gearing and financial slack is difficult to predict. The ratio of total debt to the market value of equity was used to identify equal-sized sub-samples of high, medium and low geared companies and enable comparisons of responses between high and low geared companies.

Prior research has identified a firm's industry as a potentially important determinant of capital structure. Firms characterised by high operating risk are more susceptible to financial distress. Those in cyclical sectors will suffer greater variability in profitability, while some, such as information technology firms, are subject to technological risks and typically employ firm-specific intangible assets. Further, high growth sectors may experience high agency costs through restrictions imposed by lenders to reduce the greater opportunities for asset substitution. Maintenance of financial slack might be preferred by firms in high growth sectors with ample investment opportunities. Also, different product market or competitive environments across industries may also affect capital structure decisions. Respondents were classified into nine broad industrial groupings based on Stock Exchange sectors (basic industries, cyclical consumer goods, cyclical services, information technology, general industries, non-cyclical consumer goods, non-cyclical services, resources and utilities).

\section{RESULTS}

After describing the response profile, this section covers six key areas: debt ratios; target capital structure; hierarchy in capital structure; maintenance of spare borrowing capacity; determinants of capital structure, and further analysis of size, gearing and industry effects.

\section{(i) Response profile}

From the mailing to 831 finance directors, 192 usable responses were received representing a response rate of $23 \% .{ }^{8}$ Six additional responses were received from those who requested a copy of the questionnaire when replying to a questionnaire on a related topic, ${ }^{9}$ giving a total of 198 usable responses. Prior research studies involving similar subjects have obtained response rates of between $9 \%$ and $35 \%$. The response rate in the present study is in line with recent studies and, given the length of the questionnaire, can be considered good.

Three tests for response bias were performed. First, responding companies were compared with the population of UKQI companies on the basis of size (measured as total assets). A 2-tail t-test confirmed no difference between the sample mean total assets and the population mean at the $10 \%$ significance level. ${ }^{10}$ Second, the respondent companies were formed into nine broad industrial categories based on Stock Exchange sectors and a $\chi^{2}$ goodness-of-fit test confirmed that the sample companies were distributed similarly to companies in the UKQI population $\left(\chi^{2}=9.39 ; p=0.310\right)$.

Finally, the responses of early responders were compared to those of late responders on the assumption that late responders are similar to non-responders (Oppenheim, 1966). As there were no particularly 'key' questions in the questionnaire on which to focus, a series of tests appropriate to the question form (i.e. Wilcoxon-Mann-Whitney, t-test, $\chi^{2}$ ) was conducted for the 64 closed-form question elements. As only three significant differences (at the 5\% level) emerged, the sample of respondent finance directors is likely to be representative of the population of UKQI companies and so non-response is unlikely to be a major issue in interpreting the results of the survey. ${ }^{11}$

A further factor that can affect the validity of responses is the suitability of individual respondents, in terms of knowledge about the issues under investigation. All of those who confirmed their corporate position in the final section of the questionnaire were senior financial personnel likely to be 
knowledgeable about capital structure issues: finance directors (63\%), treasurers (13\%), financial controller $(8 \%)$ or similar senior personnel $(16 \%)$.

An important contextual element in understanding respondents' views concerns their perceptions of stock market efficiency. This was assessed by asking respondents to indicate the percentage of time that their ordinary shares are fairly priced by the market. Answers suggested that most respondents do not accept the notion of market efficiency. For example, $86 \%$ felt that the market fairly priced their shares less than three-quarters of the time, ${ }^{12}$ suggesting that managers generally do not believe the market to be efficient. This compares with approximately $52 \%$ in the earlier US study by Pinegar and Wilbricht (1989), reflecting either a decline in the acceptance of market efficiency or perhaps national differences in its acceptance.

\section{(ii) Debt levels}

In response to the question 'Does your company believe that there is a maximum amount of debt financing that should not be surpassed?', $69 \%$ of respondents responded affirmatively. Thus, while the majority of companies believe that the debt level has to be constrained, a significant minority (31\%) do not believe this is necessary. Of those companies that believe debt should be limited, most (91\%) indicated that their maximum debt level is defined by reference to a limit placed on balance sheet and/or income statement gearing measures.

In a separate question, $75 \%$ of respondents confirmed that they measured financial gearing. ${ }^{13}$ Of the five different measures offered, interest cover and the net debt to equity ratio were clearly favoured. These had mean scores of 4.1 and 4.0 (on a scale from 1 (not used) to 5 (very important)), and were identified as 'important' or 'very important' by $80 \%$ and $75 \%$ of the companies that measured gearing, respectively. Of the respondents who measure gearing and are also engaged in leasing, approximately $75 \%$ claimed to recognise fixed finance and operating lease payments in calculating financial gearing measures. This could be taken to imply that a significant proportion of companies use a version of the 'fixed charge cover' measure; however, such a measure was not proposed as an alternative in the open-ended option for gearing measures. The majority of respondents that measure debt to equity ratios use book values (83\%) rather than theoretically-supported market values $(12 \%)$; $5 \%$ use both measures. Scott and Johnson (1982) found that $92 \%$ of their US respondents used book values rather than market values, suggesting that the practice may be pervasive. This observation is entirely consistent with our finding (section 4(i) above) that managers' do not generally believe the stock market to be efficient. Why would a manager adopt a policy-relevant measure that is based on share price, which is not within his control, is highly volatile and which he believes to be incorrect much of the time? Indeed, the use of book values may also have some theoretical justification since these are related to the value of assets in place rather than the value of intangibles and growth opportunities (Myers, 1984). Importantly, managers' use of book values also helps to explain why research using market value measures of equity finds that firms do not seem to adjust their capital structure to changes in equity values (Welch, 2004).

\section{(iii) Target capital structure}

In the trade-off theory of capital structure, companies are said to operate with a target debt/equity ratio at which the costs and benefits of issuing debt are balanced. Table 2 (Panels A to C) summarises the responses to a group of questions that focussed specifically on this theory. Panel A shows that approximately half of the companies $(51 \%)$ indicated that they did maintain a target capital structure. Of these, $73 \%$ claimed it to be 'flexible' and $27 \%$ 'reasonably strict'. Panel B shows that targets ranged from $0 \%$ to $300 \%$ with a mean (median) of $45 \%$ (40\%) and with $80 \%$ of companies indicating a target of $50 \%$ or less debt. Fawthrop and Terry (1975) reported a similar group norm limit of debt financing of $40 \%$ in the very different economic environment over 25 years ago.

$<$ TABLE 2 about here $>$

Even for companies with target debt levels, fluctuations in actual debt levels may be observed over time. This may be because the targets themselves are flexible, or because transaction costs lead to 
'lumpy' changes in debt or equity levels, or because the actual, or perceived, costs and benefits associated with the use of debt change over time. Two-thirds (67\%) of companies with target debt levels formally reviewed their target on a regular basis. Companies that did not review the targets regularly were asked, in an open-ended question, to specify what would trigger a review. The two most frequently quoted responses were that there was a continuous review of the capital structure target, or that reviews coincided with substantial acquisition, merger and investment activities.

Finally, to assess the main 'drivers' of capital structure targets, respondents were asked to rank nine potential influences in setting target capital structure ratios. Panel C of Table 2 suggests that the main force in setting target capital structure seems to come from within the company: company senior management were ranked the most important, significantly ahead of other potential influences. Thus, capital structure seems to be internally rather than externally constrained.

\section{(iv) Hierarchy in capital structure}

In the pecking order theory of capital structure, companies are said to relate profit and growth opportunities to their long-term target dividend pay-out ratios in order to minimise the need for external funds. Investment opportunities and dividend pay-out, therefore, dictate the amount of external financing. The flexibility of the financing decision in relation to investment and dividend decisions was investigated by asking respondents: 'Given an attractive new growth opportunity that could not be taken without departing from your existing capital structure, cutting dividend or selling off other assets, what action is your company most likely to take?'. $86 \%$ said that the company would deviate from existing capital structure, $15 \%$ would sell off other assets, $5 \%$ would forgo the growth opportunity, just $2 \%$ would cut dividends with $2 \%$ answering 'don't know' ${ }^{14}$ Companies with a target capital structure were less likely to deviate from their existing capital structure than companies that had no target $\left(\chi^{2}=9.12 ; \mathrm{p}=0.003\right)$.

The next question focused directly on the pecking order theory by asking 'Does your company follow a hierarchy in which the most favoured sources of finance are exhausted before other sources?'. $60 \%$ answered affirmatively and were asked to rank eight listed sources of finance. Both finance and operating leases were included in order to determine, for the first time, how leasing ranks in relation to other sources of finance. A summary of the rankings is shown in Table 3.

$<$ TABLE 3 about here $>$

Consistent with the pecking order theory, internal reserves were most favoured by respondents, followed by straight debt. There was a significant gap before the third-ranked group of finance sources (finance leases, operating leases and ordinary shares), with each of this third group subject to a high variation (standard deviation) in ranking. The similarity in mean rank between finance and operating leases is perhaps surprising given the predominant and prolific use of operating leases in recent years (Beattie at al., 1998).

As stated above, some prior research appears to assume that the pecking order and trade-off theories are competing descriptors of company practice. Table 4 investigates this crucial assumption by providing a cross-tabulation between the two views. $60 \%$ of respondents claimed to follow a hierarchy and $50 \%$ a target capital structure. However, $32 \%$ claimed to follow both and $22 \%$ to follow neither. If the two theories are perceived as mutually exclusive by respondents, a negative association would be expected. This was not found, suggesting that companies do not make their capital structure decisions consistent with either of these theories exclusively. A broadly similar result was found in the US where $26 \%$ of 'hierarchy' companies also claimed to have a target debt ratio (compared with $54 \%$ in the present study). Inter alia, this led Norton (1989) to conclude that 'firms seem to use an eclectic approach when considering financing alternatives'.

One possible explanation for these observations is that when a manager is faced with a financing decision at a particular point in time, he may be influenced to a greater or lesser extent by the reasoning underpinning both of the main theories. For example, imagine a manager with a belief that information asymmetry and transaction costs are so large for his firm that he adopts a fundamental 
pecking order theory approach to financing. The firm has been a net investor in recent years, with a deficit of internal resources (retained profit), so has been increasing its borrowings to the high current level. At this point in time, the manager has to decide whether to raise more debt or issue equity, and the major consideration that is likely to affect the current decision will be the relative costs. For debt, these will be the direct after-tax interest cost, transaction costs, as well as potential agency costs and, given the high debt level, significant distress costs, all costs typically associated with trade-off theory. For equity, it will be the equity required rate of return, transaction costs, together with information asymmetry costs. Thus, while the primary approach for the firm is based on pecking order theory, the current decision may be driven mainly by trade-off theory considerations. Effectively, the firm has a maximum amount of debt that it believes is optimal and so at this stage in the financing cycle it does have a target. How would the manager reply to the questions about whether the firm follows a hierarchy and whether it has a target debt level? He might answer yes to both, or recognising that the specific decision had elements of both theories, he might answer no to both since he may not consider he is exclusively adopting one theory or the other.

On the other hand, imagine a manager who typically seeks to minimise financing costs, by balancing the overall agency and distress costs of debt with the tax benefit (a trade-off theory manager). While operating with a target debt level, he may be quite happy to deviate from that level in the short-term, for example by using internal funds because of transaction costs (or even inertia). Thus he may be acting, in the short-term, within a hierarchy of financing sources. The first manager is long-term pecking-order, short-term trade-off and vice versa for the second manager. A similar line of argument, which he called 'modified pecking order', was tentatively put forward by Myers (1984) when seeking to reconcile theory and financing practice. Frank and Goyal (2003) provided an alternative description when concluding that the need for outside funds, rather than being the driving factor in capital structure decisions, was simply one factor among many that firms trade off. They suggested that the informational asymmetry aspects in the pecking order theory could most usefully be incorporated as an additional factor in a generalised version of the trade-off model.

The observation here that neither of the main theories is dominant helps to explain the diversity of evidence from empirical research studies and suggests that future theoretical work might profitably consider ways of synthesising the key elements from both theories. To support these theoretical advances, empirical work, using intensive interview-based methods, could seek to understand the contingent nature of financing decisions (i.e., the circumstances in which each of the main approaches dominates).

$<$ TABLE 4 about here $>$

\section{(v) Maintenance of spare borrowing capacity}

Myers and Majluf (1984) suggest that companies are likely to maintain spare borrowing capacity (financial slack) to avoid the need for external funds. Table 5 reports the responses to four questions investigating financial slack. Panel A shows that $59 \%$ of companies acknowledged a policy for maintaining spare borrowing capacity. For the respondents able to quantify the level, the estimated slack ranged between $0 \%$ and $100 \%$ of existing total long-term debt with a majority $(64 \%)$ within the $1-25 \%$ range; the mean was $29 \%$ (Panel B). Most of these companies used an overdraft facility as the source of slack with secured and unsecured loans, and leasing/hire purchase as other significant sources (Panel C). All of the four offered reasons why companies might maintain slack were accepted by a substantial proportion of respondents: unplanned opportunities; for acquisitions; as a reserve for crisis; and for special projects (Panel D).

$<$ TABLE 5 about here $>$

Thus, there is some evidence consistent with the pecking order theory suggestion of the need for financial flexibility. However, flexibility is also important for reasons unrelated to the theory (Opler et al., 1999). Further, under the pecking order theory, companies adopt a hierarchy of financial sources and are likely to maintain financial slack. This expected positive association is not evident in a crosstabulation between responses to the two questions about hierarchy and slack $\left(\chi^{2}=0.39 ; p=0.534\right)$. 


\section{(vi) Determinants of capital structure}

The factors determining the choice of capital structure were explored in two questions, the first dealing specifically with the responding company's decisions and the second relating more generally to decisions by listed UK companies. By framing the second question more generally, the potentially sensitive nature of a firm-specific question can be reduced. For example, a respondent might not recognise (and/or acknowledge) agency problems in his/her own firm but might accept that other firms suffer from agency problems.

In the first question, respondents were asked the relative importance of thirteen factors in choosing an appropriate amount of total debt for their company. Panel A of Table 6 summarises mean responses in order of importance. The factors included two basic issues concerning the projected benefits from the assets financed (row 2) and the volatility of company earnings/cash flows (row 3). Several factors related to the traditional trade-off theory's balance between the benefits and costs of using debt: interest tax shield benefits (row 7); the availability of non-debt tax shields (row 10); interest costs (row 6); bankruptcy costs (row 9 and, indirectly, row 1); and the personal tax costs of lenders (row 13). Two agency cost factors were included: reducing free cash to control management (row 12); restrictive debt covenants (row 5). Two factors concerned corporate control issues: take-over target likelihood (row 11) and equity dilution (row 8). Finally, one factor focussed on customer/supplier attitudes (row 4), addressing the issue of firm-stakeholder interaction.

$<$ TABLE 6 about here $>$

The most important factor in determining the appropriate debt level was ensuring long term survivability of the company. This suggests that avoidance of bankruptcy (or perhaps take-over) features highly in debt level decisions. However, somewhat inconsistently, the direct factor 'potential costs of bankruptcy' was only considered fairly important, but with high response variability. The factor with the second-highest mean response was the projected cash flow/earnings from the assets financed. There was a relatively high level of agreement on the two main factors as indicated by the low variability.

A group of three factors (rows 3-5) rated third highest in importance. Two of these related indirectly to bankruptcy costs while the third was an agency cost of debt; close behind (row 6) was the level of interest rates. Three of these four features are consistent with the trade-off theory. Similarly, of the next set of four factors grouped around a mean score of 3 ('fairly important'), three also support the trade-off theory (rows 7, 9 and 10). However, one (row 8), avoiding the issue of equity and associated equity dilution, is consistent with the pecking-order theory.

Takeover prevention (row 11), disciplinary control of managers (row 12) and the personal tax cost of lenders (row 13) were not seen as particularly important, the latter suggesting that companies do not target a clientele of investors with certain tax characteristics.

The second question concerning capital structure determinants asked respondents to indicate the extent of their agreement with 17 general statements in the context of UK listed companies' financing decisions. Seven of the statements concerned the issue of asymmetric information (rows 1, 3, 6, 7, 9, 14 and 17), three considered agency costs (rows 4, 8 and 12) and two related to interest tax shield (rows 2 and 11). Statements also dealt directly with the trade-off theory (row 15), the pecking order theory (row 13), competitive strategy/agency costs (row 5), corporate control (row 16), and market frictions (row 10). A summary of respondents' views, in descending order of agreement, is provided in Panel A of Table 7.

\section{$<$ TABLE 7 about here $>$}

Respondents agreed most strongly that, in making debt and equity decisions, a company considers the market response to new issues of debt and equity ( $88 \%$ agreed). This suggests that respondents may be concerned, at least implicitly, about information asymmetry between management and investors, a 
justification for the pecking order theory. In addition, one of the three other statements receiving a 'high' level of agreement ( $>60 \%$ agreed) relates to information asymmetry (row 3), while also reflecting managers' general views that the market is not efficient in pricing equity (section 4(i) above). The other two relate to interest tax shield (row 2), and agency costs (row 4), consistent with the trade-off theory.

Two further statements received 'moderate' agreement ( $>40 \%$ agreed). One concerned competitive strategy/agency costs (row 5), and the other related to information asymmetry (row 6).

Significant disagreement was recorded for seven statements. Respondents disagreed most strongly with the information asymmetry argument that issuing shares sends unfavourable signals concerning future long-term prospects (row 17; 75\% disagreed). This response is not consistent with empirical evidence that share issues are associated with future return underperformance, on average (Spiess and Affleck-Graves, 1995; Loughran and Ritter, 1995). Finance directors may not know about the evidence, may not believe it, or may not want to believe it since it would constrain their potential future financing choices. Respondents also strongly rejected the 'corporate control' argument that a company would issue shares to dilute the holdings of certain shareholders (row 16).

Of particular interest is the strong rejection of the fundamental logic of the trade-off theory, that the present value of interest tax shields is balanced with the present value of possible bankruptcy costs (row 15). However, given that this is inconsistent with other responses concerning elements of the theory (discussed above), one explanation might be that respondents were rejecting the notion of formal quantitative evaluation rather than the underlying logic. Nevertheless, the logic of the pecking order theory fares little better since respondents disagreed that a company issues debt when recent profits are not sufficient to fund activities (row 13). They also disagreed that share price usually declines when debt is issued (row 14) and, perhaps surprisingly, that the decision to issue debt or equity is affected by the existence of tax loss carry forwards (row 11).

Respondents acknowledged the adverse consequences of bankruptcy from a personal perspective by rejecting the notion that, if bankruptcy occurred, finance directors would find comparable positions of employment elsewhere (row 12). This lends support to the Grossman and Hart (1982) argument that issuing debt may encourage directors to perform better in order to reduce the likelihood of bankruptcy.

(vii) Size, gearing and industry effects

The extent to which opinions on capital structure decisions are related to company size, gearing level and industry group factors was investigated.

\section{Size effects}

The likelihood of adopting a target capital structure was found to be associated with company size (Table 2, Panel A: $\chi^{2}=8.51 ; p=0.014$ ). Further partitioning analysis (p. 194, Siegel and Castellan, 1988) confirmed that large companies were more likely to have a target capital structure, and that small companies were more likely to have no target. This is consistent with the argument that large companies have greater control over their capital structure than small companies and may reflect large companies' greater access to finance, their response to stock market pressures or deliberate internal policy choice. By contrast, the preference for a hierarchy of sources of finance was independent of company size $\left(\chi^{2}=2.17 ; \mathrm{p}=0.339\right)$. However, large companies $(71 \%)$ were more likely to maintain financial slack than medium (66\%) or small $(41 \%)$; the association between size and financial slack was highly significant $\left(\chi^{2}=13.82 ; p=0.001\right)$. This probably reflects the inability of small companies to create financial slack, but is also consistent with larger companies maintaining financial flexibility to reduce the need to raise external funds.

Table 6 (Panel B, column 1) shows that large companies are more positive than small companies in their response concerning three determinants of their own total debt level: the tax advantages of interest deductions; avoiding the need to issue dilutive equity; and preventing the company from 
becoming a take-over target. The first indicates a greater concern for taxation issues that may reflect higher profitability in larger companies, lower agency costs or perhaps the higher tax rate that they often suffer. The second is somewhat surprising since small companies are likely to include more owner-managers than large. It possibly reflects the fact that small companies find it more difficult to access 'new equity' markets, so the prospect of an equity issue is not in the mind-set of managers. The third might reflect a greater awareness in large companies of the opportunities for using debt to reduce the likelihood of takeover or perhaps that takeovers, as potentially attractive exit strategies, are viewed positively by some small firm owner-managers.

Only one significant company size-based difference was observed in Table 7 (Panel B, column 1). Large firms more strongly disagreed with the suggestion that share price usually declines when debt is issued, perhaps reflecting their greater experience of major debt issues.

\section{Gearing effects}

From the responses obtained, there is some evidence that high geared companies are more likely to adopt a target capital structure, and weaker evidence that they are more likely to follow a hierarchy of finance and to maintain financial slack than low geared companies. The statistical significance of the associations is sensitive to the particular definitions of gearing and to the test applied. The cause and effect relationship here is unclear. The evidence might suggest that companies that find themselves in a situation of high gearing focus more closely on controlling, or justifying, the high debt levels. Alternatively, companies that more deliberately adopt a particular capital structure strategy might be able to accommodate (or justify) higher gearing levels. Unfortunately, it is also possible that gearing is proxying for size here. Although absolute levels of company size and gearing are not significantly correlated, the three size categories are significantly positively associated with the three gearing categories.

Table 6 (Panel B, column 2) indicates that more highly geared companies are particularly concerned about projected cash flows, presumably whether they will cover interest charges. Not surprisingly, they are also more focussed on debt covenants than companies with low gearing. The relative importance of other (non-interest) tax shields to high geared companies is consistent with the argument that these can be substitutes for interest in seeking to minimise tax liabilities (DeAngelo and Masulis, 1980).

Two significant differences were observed in Table 7 (Panel B, column 2). High geared companies were more ready to accept the view that a company would issue debt when equity is undervalued by the market; this might be ex post justification that the respondents' own company's high debt level is a rational consequence of information asymmetry. Low geared companies more strongly rejected the view that a company issues debt when recent profits are not sufficient to fund activities.

\section{Industry effects}

Cross-tabulations indicate that the likelihood of companies adopting a target capital structure, or of following a hierarchy of financial sources, is not associated with industry classification. Thus, there is little evidence here that companies within particular stock exchange sectors adopt similar financing strategies. By contrast, the likelihood of maintaining financial slack does seem to differ across sectors $\left(\chi^{2}=12.93 ; p=0.044\right)$. Further partitioning analysis shows that fewer companies in the non-cyclical consumer goods sector (39\%) maintain slack, but more companies in the cyclical consumer goods $(80 \%)$ and information technology $(78 \%)$ sectors do so. ${ }^{15}$ The differences are consistent with the expected greater cash flow variability and operating risk in the latter two sectors.

Industry variation in opinions on firm-specific financing decisions is indicated in Panel B, column 3, of Table 6, with two significant differences observed. First, industry variation in the maintenance of slack (previous paragraph) is mirrored by reduced concern about projected cash flows/earnings in information technology and cyclical consumer goods, and greater concern in non-cyclical consumer goods. Utilities and resource sectors also have significantly greater concern about cash flows. A possible explanation might be that the different concerns about cash flows reflect current gearing 
levels. However, while there are (non-significant) differences in industry-average gearing levels, these do not appear to correlate with concerns about cash flows. Second, opinions on whether 'preventing the company from becoming a take-over target' influences a firm's debt level are cross-sectorally quite diverse. At one extreme, resources and information technology sectors argue that this is of little importance but, at the other, non-cyclical services (i.e. food and drug retailers) consider it to be moderately important. This may reflect industry-specific differences in take-over fears.

Just one significant industry-sensitive response was observed in Table 7 (Panel B, column 3). Respondents' views on the relationship between $R \& D$ dependence and gearing (row 5) were somewhat diverse (high standard deviation), with utilities disagreeing but resources companies agreeing quite strongly that gearing would be lower for R\&D dependent firms.

\section{SUMMARY AND DISCUSSION}

While respondents' views on specific features of corporate financing decisions have intrinsic interest, the relationship between their views from practice and extant theories is of particular importance. Table 8 seeks to summarise the evidence from the questionnaire in relation to each of the theories and elements of theories.

$<$ TABLE 8 about here $>$

Certain elements appear to have strong support and are generally consistent with results from UK regression studies (references in brackets): the tax advantage of debt interest (Walsh and Ryan, 1997); the need for collateral in debt contracts constraining the use of debt (asset tangibility influence: Bennett and Donnelly, 1993; Adedeji, 1998; Bevan and Danbolt, 2004); consideration of the market response to debt or equity issues (Marsh, 1984); and companies issuing debt when they feel that equity is undervalued. Respondents' concern about long-term company survivability is difficult to reconcile with UK regression results which report a positive relationship between debt and earnings variability (Bennett and Donnelly, 1993).

On the other hand, certain arguments are strongly refuted. Perhaps surprisingly, respondents do not agree that interest tax shields are formally balanced with bankruptcy costs, one of the fundamental features of the trade-off theory. There are, however, potential behavioural explanations for the other four refutations. For example, respondents do not consider the personal tax circumstances of debt providers but, given the difficulty of doing so, this is perhaps not surprising. Similarly, they do not accept the agency theory argument (a supposed benefit) that using debt commits a large proportion of cash flow to interest payments thereby acting as a control on management's potential excesses. Again, this may not be surprising since it requires an admission by managers' that their and other stakeholders' objectives are sometimes in conflict. Respondents do not agree that shares are issued to dilute certain shareholders' interests, perhaps because this may denote self-interested (unethical?) political manoeuvring against some shareholders, or simply because managers have not been in a position where it was necessary to contemplate such an action. Finally, as suggested earlier, it is not surprising that managers do not believe that issuing shares sends unfavourable signals to the market.

There is evidence that many of the theoretical arguments are accepted by a significant number of respondents: the importance of interest tax shield (consistent with Walsh and Ryan, 1997), financial distress, agency costs (consistent with Walsh and Ryan, 1997 and, for large companies, Lasfer, 1998) also, at least implicitly, information asymmetry. The use of debt as an instrument in corporate control situations is not generally accepted.

Consistent with the trade-off theory, half of the respondents consider that their firms adopt a target capital structure. But $60 \%$ claim to follow a hierarchy of sources of finance, and these firms tend to rank the attractiveness of sources as expected in the pecking order theory. While 59\% of firms maintain financial slack, this flexibility is valued by firms generally rather than just by 'hierarchy' firms. The two 'competing' capital structure theories are not accepted as mutually-exclusive (or exhaustive) by all respondents, since some firms adopt (at least partially) both strategies, while a significant number of firms do not appear to follow either of these strategies. Such observations raise 
concerns about the usefulness of large-scale regression modelling of capital structure determinants. In normal usage, these models can only describe whether a particular theory is consistent with the observed capital structure of the 'average firm' in the population. They are not typically used to model the diversity of capital structure practice.

As with most UK regression-based determinant studies (Bennett and Donnelly, 1993; Lasfer, 1995; Bevan and Danbolt, 1998; Ozkan, 2001; Bevan and Danbolt; 2004), there is clear evidence that company size affects corporate financing decisions. For example, large companies are more likely to adopt a target debt level and to maintain financial slack (though not more likely to follow a hierarchy of finance). Similarly, current high levels of gearing encourage a greater focus on particular issues such as projected cash flows, loan covenants and non-interest tax shields. This contingency on debt levels suggests that empirical studies of capital structure dynamics may be particularly fruitful (see, for example, Hovakimian et al. (2001) and references therein; and Shyam-Sunder and Myers (1999) for an illustration of the difficulties involved). In contrast with some UK regression studies (Bennett and Donnelly, 1993; Adedeji, 1998), there is little evidence here that firms in specific industries adopt similar financing strategies; however, the importance of financial flexibility in terms of maintenance of financial slack does appear to be industry-related.

\section{CONCLUSION}

Overall, the results suggest that current theories of capital structure all contribute to decision-making practice though certain aspects of the theories are strongly refuted. Importantly, finance directors' opinions are not fully consistent with either of the main theories. There are several possible reasons for this. Clearly, the capital structure decision is a complex, multi-dimensional problem. Humans have bounded rationality (Simon, 1957), so it would be surprising if all factors were considered. In addition, some responses may reflect organisational inertia, which makes organisations slow to adapt to changes in the relevant environment (Hannan and Freeman, 1984). Moreover, financing decisions are likely to be the product of complex group processes. Capital structure theory is not (yet) able to capture these complexities. Although dynamic regression models are beginning to recognise that relationships might vary over time, models that incorporate elements of both trade-off theory and pecking order theory might be a fruitful line of enquiry.

The study also suggests that attention should be given to seeking a better understanding of the diversity and complexity of firms' capital structure decisions rather than simply describing the associations between capital structure outcomes and firm-specific characteristics for the 'average firm'. In view of our finding that managers do not believe the market to be efficient, future research might also usefully consider alternative decision models which are less founded on rational economics. In-depth case study observations of individual firms' financing decisions, and particularly of changes over time would be especially valuable in exploring this diversity and related behavioural effects. 


\section{REFERENCES}

Adedeji, A. (1998), 'Does the Pecking Order Hypothesis Explain the Dividend Payout Ratio of Firms in the UK?', Journal of Business Finance \& Accounting, Vol. 25, Nos. 9/10 (November/December), pp. 1127-55.

Adedeji, A. (2002), 'A Cross-sectional Test of Pecking Order Hypothesis Against Static Trade-off Theory on UK Data', Unpublished work.

Allen, D.E. (1991), 'The Determinants of the Capital Structure of Listed Australian Companies: the Financial Manager's Perspective', Australian Journal of Management, Vol. 16, No. 2, pp. 103-28.

Allen, D.E. (1999), 'Spare Debt Capacity: Company Practices in Australia, Britain and Japan', Working Paper (School of Finance and Business Economics, Edith Cowan University, Australia).

Antoniou, A., Y. Guney and K. Paudyal (2002), Determinants of Corporate Capital Structure: Evidence from European Countries', Working Paper (Centre for Empirical Research in Finance, University of Durham, Durham).

Baker, M. and J. Wurgler (2002), 'Market Timing and Capital Structure', Journal of Finance, Vol. 57, No. 1, pp. 1-30.

Bancel, F. and U.R. Mittoo (2002), 'The Determinants of Capital Structure Choice: a Survey of European Firms', Working paper, presented at EFMA 2002, London and available from SSRN at http://papers.ssrn.com/paper.taf?abstract_id=299172.

Barclay, M.J. and C.W. Smith (1995), 'The Priority Structure of Corporate Liabilities', Journal of Finance, Vol. 50, No. 3 (July), pp. 899-917.

Barclay, M.J. and C.W. Smith (1999), 'The Capital Structure Puzzle: Another Look at the Evidence', Journal of Applied Corporate Finance, Vol. 12, No. 1 (Spring), pp. 8-20.

Barton, S.L. and P.L. Gordon (1988), 'Corporate Strategy and Capital Structure', Strategic Management Journal, Vol. 9, No. 6 (November), pp. 623-32.

Beattie, V., K. Edwards, and A. Goodacre (1998), 'The Impact of Constructive Operating Lease Capitalisation on Key Accounting Ratios', Accounting and Business Research, Vol. 28, No. 4 (Autumn), pp. 233-54.

Beattie, V., Goodacre, A. and S.J. Thomson (2003), 'Determinants of Leasing Choice in Corporate Financing Decisions: UK Survey Evidence', presented at British Accounting Association Annual Conference 2003, Manchester, 23-25 April.

Bennett, M. and R. Donnelly (1993), 'The Determinants of Capital Structure: Some UK Evidence', British Accounting Review, Vol. 25, No. 1, pp. 43-59.

Bevan, A.A. and J. Danbolt (2002), 'Capital Structure and its Determinants in the UK - a Decompositional Analysis', Applied Financial Economics, Vol. 12, No. 3 (March), pp. 159-70.

Bevan, A.A. and J. Danbolt (2004), 'Testing for Inconsistencies in the Estimation of UK Capital Structure Determinants', Applied Financial Economics, Vol. 14, No. 1 (January), pp. 55-66.

Bourque, L.B. and Fielder, E.P. (1995), How to conduct self administered and mail surveys, The Survey Kit TSK3, Sage Publications.

Brounen, D., de Jong, A. and Koedijk, K. (2004), 'Corporate Finance in Europe: Confronting Theory with Practice', Working Paper (Erasmus University, Rotterdam).

DeAngelo, H. and R.W. Masulis (1980), 'Optimal Capital Structure Under Corporate and Personal Taxation', Journal of Financial Economics, Vol. 8, No. 1 (March), pp. 3-29.

Dissanaike, G., B.M. Lambrecht and A. Saragga (2001), 'Differentiating Debt Target from Non-target Firms: an Empirical Study on Corporate Capital Structure', Working Paper (Judge Institute of Management Studies, Cambridge).

Donaldson, G. (1961), Corporate Debt Capacity: a Study of Corporate Debt Policy and the Determination of Corporate Debt Capacity (Harvard Graduate School of Business Administration, Boston).

Fama, E.F. and K.R. French (2002), 'Testing Tradeoff and Pecking Order Predictions about Dividends and Debt', Review of Financial Studies, Vol. 15, No. 1, pp. 1-33. 
Fawthrop, R.A. and B. Terry (1975), 'Debt Management and the Use of Leasing Finance in UK Corporate Financing Strategies, Journal of Business Finance \& Accounting, Vol. 2, No. 3 (Autumn), pp. 295-314.

Flannery, M.J. and Rangan, K.P. (2003), ‘Partial Adjustment toward Target Capital Structures', Working Paper.

Frank, M.Z. and V.K. Goyal (2003), 'Testing the Pecking Order Theory of Capital Structure', Journal of Financial Economics, Vol. 67, No. ?, pp. 217-48.

Graham, J.R. and C.R. Harvey (2001), 'The Theory and Practice of Corporate Finance: Evidence from the Field', Journal of Financial Economics, Vol. 60, Nos. 2/3 (May), pp. 187-243.

Graham, J.R., M.L. Lemmon and J.S. Schallheim (1998), 'Debt, Leases, Taxes and The Endogeneity of Corporate Tax Status', Journal of Finance, Vol. 53, No. 1 (February), pp. 131-62.

Grinblatt, M. and S. Titman (1998), Financial Markets and Corporate Strategy (Irwin/McGraw-Hill, USA).

Grossman, S.J. and O. Hart (1982), 'Corporate Financial Structure and Managerial Incentives', in McCall, J. (ed), The Economics of Information and Uncertainty (University of Chicago Press, Chicago), pp. 107-37.

Hannan, M.T. and J.H. Freeman (1984), 'Structural Inertia and Organizational Change', American Sociological Review, Vol. 49, No. 2 (April), pp. 149-64.

Harris, M. and A. Raviv (1988), 'Corporate Control Contests and Capital Structure', Journal of Financial Economics, Vol. 20, pp. 55-86.

Harris, M. and A. Raviv (1991), 'The Theory of Capital Structure', Journal of Finance, Vol. 46, No. 1 (March), pp. 297-355.

Hovakimian, A., T. Opler and S. Titman (2001), 'The Debt-Equity Choice', Journal of Financial and Quantitative Analysis, Vol. 36, No. 1 (March), pp. 1-24.

Jensen, M.C. (1986), 'Agency Costs of Free Cash Flow, Corporate Finance and Takeovers', American Economic Review, Vol. 76, pp. 323-39.

Jensen, M.C. and W. Meckling (1976), 'Theory of the Firm: Managerial Behaviour, Agency Costs, and Capital Structure', Journal of Financial Economics, Vol. 3, No. 4 (October), pp. 305-60.

Lasfer, M.A. (1995), 'Agency Costs, Taxes and Debt: the UK Evidence' European Financial Management, Vol. 1, No. 3, pp. 265-85.

Lasfer, M.A. (1999), 'Debt Structure, Agency Costs and Firm's Size: an Empirical Investigation', Working Paper (City University Business School, London).

Leary, M. and M.R. Roberts (2003), 'Do Firms Rebalance their Capital Structure?', Working Paper (Fuqua School of Business, Duke University).

Loughran, T. and Ritter, J.R. (1995), 'The New Issues Puzzle', Journal of Finance, Vol. 50, No. 1, pp. 23-51.

Mangione, T.W. (1995), Mail surveys improving the quality, Applied Social Research Methods Series, Vol. 40, Sage Publications.

Marsh, P. (1982), 'The Choice Between Equity and Debt: an Empirical Study', Journal of Finance, Vol. 37, No. 1 (March), pp. 121-44.

Mehran, H., R.A. Taggart and D. Yermack (1999), 'CEO Ownership, Leasing and Debt Financing', Financial Management, Vol. 28, No. 2 (Summer), pp. 5-15.

Modigliani, F.F. and M.H. Miller (1958), 'The Cost of Capital, Corporation Finance, and the Theory of Investment', American Economic Review, Vol. 48, No. 3 (June), pp. 261-97.

Modigliani, F.F. and M.H. Miller (1963), 'Corporation Income Taxes and the Cost of Capital: a Correction', American Economic Review, Vol. 53, No. 3 (June), pp. 433-43.

Myers, S.C. (1977), 'Determinants of Corporate Borrowing', Journal of Financial Economics, Vol. 5, No. 2 (November), pp. 147-75.

Myers, S.C. (1984), 'The Capital Structure Puzzle', Journal of Finance, Vol. 39, No. 3 (July), pp. $575-92$ 
Myers, S.C., and N.S. Majluf (1984), 'Corporate Financing and Investment Decisions when Firms Have Information Investors Do Not Have', Journal of Financial Economics, Vol. 13, No. 2 (June), pp. 187-221.

Norton, E. (1989), 'Determinants of capital structure: a survey', Advances in Financial Planning and Forecasting, Vol. 3, pp. 323-50.

Opler, T.C., L. Pinkowitz, R. Stulz and R. Williamson (1999), 'The Determinants and Implications of Corporate Cash Holdings', Journal of Financial Economics, Vol. 52, No. 1 (April), pp. 3-46.

Oppenheim, A.N. (1966), Questionnaire Design and Attitude Measurement (Heinemann).

Ozkan, A. (2001), 'Determinants of Capital Structure and Adjustment to Long Run Target: Evidence from UK Company Panel Data', Journal of Business Finance \& Accounting, Vol. 28, Nos. 1/2 (January/March), pp. 175-98.

Pinegar, J.M. and L. Wilbricht (1989), 'What Managers Think of Capital Structure: a Survey', Financial Management, Vol. 18, No. 4 (Winter), pp.82-91.

Rajan, R.G., and L. Zingales (1995), 'What Do We Know About Capital Structure Choice? Some Evidence from International Data', Journal of Finance, Vol. 50, No. 5 (December), pp. 1421-60.

Sarkar, S. and F. Zapatero (2003), 'The Trade-off Model with Mean Reverting Earnings: Theory and Empirical Tests', Economic Journal, Vol. 113, October, pp. 834-60.

Scott, D.F. and D.J. Johnson (1982), 'Financing Policies and Practices in Large Corporations', Financial Management, Vol. 11, No. 2 (Summer), pp. 51-9.

Shyam-Sunder, L. and S.C. Myers (1999), 'Testing Static Tradeoff Against Pecking Order Models of Capital Structure', Journal of Financial Economics, Vol. 51, No. 2 (February), pp.219-44.

Siegel, S. and N.J. Castellan (1988), Nonparametric Statistics for the Behavioural Sciences (Second International Edition, McGraw-Hill, Singapore).

Simon, H.A. (1957), Models of Man, (Wiley, New York).

Spiess, D. K. and Affleck-Graves, J. (1995), 'Underperformance in Long-Run Stock Returns Following Seasoned Equity Offerings', Journal of Financial Economics, Vol. 38, No.3 (July), 243267.

Stonehill, A., T. Beekhuisen, R. Wright, L. Remmers, N. Toy, A. Pares, A. Shapiro, D. Egan and T. Bates (1975), 'Financial Goals and Debt Ratio Determinants: a Survey of Practice in Five Countries', Financial Management, Vol. 4, No. 3 (Autumn), pp. 27-41.

Thomson, S.J. (2003), 'The Role of Leasing in UK Corporate Financing Decisions, Accounting Treatment and Market Impact', PhD Thesis, University of Stirling.

Tufano, P. (2001), 'HBS-JFE Conference Volume: Complementary Research Methods', Journal of Financial Economics, Vol. 60, No. 2/3 (May), pp. 179-85.

Wallace, R.S.O. and C.J. Mellor (1988), 'Nonresponse Bias in Mail Accounting Surveys: a Pedagogical Note', British Accounting Review, Vol. 20, No. 2 (August), pp. 131-39.

Wallace, R.S.O. and T.E. Cooke (1990), 'Nonresponse Bias in Mail Accounting Surveys: a Pedagogical Extension', British Accounting Review, Vol. 22, No. 3 (September), pp. 283-88.

Walsh, E.J. and J. Ryan (1997), 'Agency and Tax Explanations of Security Issuance Decisions', Journal of Business Finance \& Accounting, Vol. 24, Nos. 7/8 (September), pp. 943-961.

Welch, I. (2004), 'Capital Structure and Stock Returns', Journal of Political Economy, Vol. 112, No.1 (February), pp. 106-31.

Williamson, O.E. (1988), 'Corporate Finance and Corporate Governance', Journal of Finance, Vol. 43, No. 3 (July), pp. 567-91. 


\section{ENDNOTES}

${ }^{1}$ Tufano's (2001) definition of clinical research, 'empirical work that examines a relatively small number of events intensively', encompassed case study research, small-scale research such as industry-level studies and surveys. He suggested that large-sample empirical evidence, while seeking to reject theories, often ends up simply confirming them, which is a much weaker form of research.

${ }^{2}$ It is feasible to specifically model the possibility of different financing approaches being adopted by firms. For example, Dissanaike et al. (2001) found evidence that one financing approach is not likely to be descriptive for all UK firms.

${ }^{3}$ Since completing the present study two further working papers making international comparisons of corporate finance practice based on a survey have become available. The first (Bancel and Mittoo, 2002) provided a preliminary analysis based on just 61 respondents spanning 17 European countries, including 7 from the UK. The second (Brounen et al., 2004) replicated and extended the Graham and Harvey (2001) study internationally with 313 respondents, including 65 from the UK.

${ }^{4}$ Large sample studies offer statistical power and cross-sectional variation but often have weaknesses related to variable specification and the inability to ask qualitative questions. Intensive case studies (less commonly used in finance research) offer excellent detail and allow the exploration of unique aspects of corporate behaviour, but necessarily involve small samples and usually give sample-specific, non-generalisable, results. The survey approach offers a balance between these two extremes. Moderately large samples provide statistical power and a broad cross-section of sample firms; at the same time, very specific and qualitative questions about behaviour and contextual factors can be asked. Of course, survey analysis is not without its own potential problems. These include the risk that respondents are not representative of the population of firms, and that the survey questions may be misinterpreted or misunderstood.

${ }^{5}$ Questions on the responding company's leasing policy were addressed in Section C (five pages) and are reported in a separate paper (Beattie et al., 2003).

${ }^{6}$ The three size sub-samples $(\mathrm{n}=66)$, based on total assets, were: large $>£ 140 \mathrm{~m} \geq$ medium $\geq £ 27.7 \mathrm{~m}>$ small. The three gearing sub-samples, based on total debt/equity MV, were: $619 \% \geq$ high $\geq 37 \%>$ medium $>8 \%>$ small $\geq 0 \%$.

${ }^{7}$ At the time when the questionnaire was issued (during the financial year ending 31 March 2001), the standard UK corporation tax rate of $30 \%$ applied to companies with taxable profits above $£ 1.5$ million. This tapered down to $20 \%$ for profits between $£ 50-300,000$ and down to $10 \%$ for profits below $£ 10,000$.

${ }^{8}$ Including 225 negative responses, the overall response rate was 50\%. The major reasons given for negative response were lack of time/staff availability/too busy $(40 \%)$, and company/individual policy not to respond to questionnaires (24\%).

${ }^{9}$ A questionnaire investigating 'lease accounting reform' was sent out over a similar time period to the remaining one-third of the UKQI population. Respondents to this survey were invited to request the 'leasing and corporate financing decisions' questionnaire and six requested and completed the questionnaire.

${ }^{10}$ The 198 companies of the responding finance directors ranged in size (total assets) from $£ 17,288$ million down to $£ 701,000$ with a mean and median of $£ 872$ million and $£ 71$ million, respectively. The population mean and median were $£ 637 \mathrm{~m}$ and $£ 52 \mathrm{~m}$, respectively.

${ }^{11}$ These tests suffer from a number of well-known limitations; see Wallace and Mellor (1988) and Wallace and Cooke (1990) for discussions.

${ }^{12}$ More specifically, the number of respondents who felt that their company's ordinary shares are fairly priced $0 \%$ of the time (i.e. never) was $26 ; 1-25 \%$ of the time was $63 ; 26-75 \%$ of the time was $73 ; 76-99 \%$ of the time was 24 ; and $100 \%$ of the time (i.e. always) was 2 .

${ }^{13}$ Not surprisingly, there was a strong degree of association $\left(\chi^{2}=36.2 ; p<0.001\right)$ between companies that 'believe there is a maximum debt level that should not be surpassed' and companies that measure gearing. Of the 47 companies that said they did not measure gearing, 13 had zero total debt. 
${ }^{14}$ Percentages sum to more than $100 \%$ as 16 respondents ticked more than one option.

${ }^{15}$ It was necessary to combine the three sectors with small representation in the sample for the formal chisquared test and the combined grouping was close to the overall average for maintenance of slack. 
Table 1: Findings of prior survey research on capital structure determinants

\begin{tabular}{|c|c|c|c|c|}
\hline Author(s) & Year & Respondents & $\begin{array}{l}\text { Response } \\
\text { rate }\end{array}$ & Conclusions drawn by author(s) \\
\hline \multicolumn{5}{|l|}{ US Setting } \\
\hline Donaldson & 1961 & $\begin{array}{l}25 \text { large US } \\
\text { corporations }\end{array}$ & na & $\begin{array}{l}\text { Hierarchy of financing sources } \\
\text { Supports pecking order theory }\end{array}$ \\
\hline $\begin{array}{l}\text { Scott \& } \\
\text { Johnson }\end{array}$ & 1982 & $\begin{array}{c}\text { CFO's of } \\
212 \text { of Fortune } \\
1000 \text { firms }\end{array}$ & $21.2 \%$ & $\begin{array}{l}\text { Firms have target leverage ratios and accept the notion of optimal } \\
\text { capital structure } \\
\text { Supports trade-off theory }\end{array}$ \\
\hline $\begin{array}{l}\text { Pinegar \& } \\
\text { Wilbricht }\end{array}$ & 1989 & $\begin{array}{l}\text { CFO's of } \\
176 \text { of Fortune } \\
500 \text { firms }\end{array}$ & $35.2 \%$ & $\begin{array}{l}\text { Evidence supports the use of a financing hierarcy } \\
\text { Supports pecking order theory }\end{array}$ \\
\hline Norton & 1989 & $\begin{array}{l}\text { CFO's of } \\
98 \text { of Fortune } \\
500 \text { firms }\end{array}$ & $21 \%$ & $\begin{array}{l}\text { Some evidence of target ratios, hierarchy of sources. No evidence of } \\
\text { a trade-off or asymmetric information or agency costs. } \\
\text { Mixed evidence }\end{array}$ \\
\hline $\begin{array}{c}\text { Graham \& } \\
\text { Harvey }\end{array}$ & 2001 & $\begin{array}{c}\text { CFO's of } \\
392 \text { of Fortune } \\
500 \text { firms and } \\
4400 \text { FEI } \\
\text { members } \\
\text { (4587 population) }\end{array}$ & $8.5 \%$ & $\begin{array}{l}\text { Target debt ratio to maintain financial flexibility. Moderate importance of } \\
\text { tax implications, less emphasis on financial distress. Interest cost of } \\
\text { debt of moderate importance. } \\
\text { Supports trade-off theory } \\
\text { Moderate evidence that debt issued when recent profits insufficient and } \\
\text { equity issues affected by market valuation. } \\
\text { No significant consideration of agency costs/benefits, corporate control } \\
\text { Supports pecking order theory }\end{array}$ \\
\hline \multicolumn{5}{|c|}{ Settings other than US } \\
\hline $\begin{array}{l}\text { Fawthrop } \\
\& \text { Terry }\end{array}$ & 1975 & $\begin{array}{l}54 \text { major UK } \\
\text { corporations }\end{array}$ & na & $\begin{array}{l}\text { Use of debt ratios to constrain debt limits. Importance of maintaining } \\
\text { financial flexibility. }\end{array}$ \\
\hline $\begin{array}{l}\text { Stonehill } \\
\text { et al. }\end{array}$ & 1975 & $\begin{array}{l}\text { Firms in US, } \\
\text { Japan, France, } \\
\text { Norway, Holland }\end{array}$ & na & $\begin{array}{l}\text { No debt ratio maintained, take advantage of favourable opportunities to } \\
\text { issue debt or equity. } \\
\text { Conflicting both pecking order and trade-off theories }\end{array}$ \\
\hline Allen & 1991 & $\begin{array}{c}48 \text { listed } \\
\text { Australian } \\
\text { corporations }\end{array}$ & na & $\begin{array}{l}\text { Some evidence on target debt ratios and tax implications of debt. Most } \\
\text { concern with maintaining spare debt capacity. Internal funds marginally } \\
\text { favoured. Supports pecking order theory }\end{array}$ \\
\hline Allen & 1999 & $\begin{array}{l}132 \text { Australian } \\
67 \text { Large UK } \\
53 \text { Japanese }\end{array}$ & $\begin{array}{l}24 \% \\
13 \% \\
10 \%\end{array}$ & $\begin{array}{l}\text { UK and Australian firms maintain spare debt capacity to be in a position } \\
\text { to seize opportunities or make acquisitions. Supports pecking order theory } \\
\text { Not so in Japanese firms. }\end{array}$ \\
\hline
\end{tabular}




\section{Question asked}

Panel A

To what extent does your company seek to maintain a target capital structure by using approximately constant proportions of debt and equity finance (even if the policy is one of zero debt finance)?

Target

No target

Target

\section{Company size (No of companies)}

\begin{tabular}{ccc|c} 
Large & Medium & Small & Total \\
\hline 22 & 35 & 38 & $95(49 \%)$ \\
43 & 30 & 28 & $101(51 \%)$ \\
\hline 65 & 65 & 66 & $196(100 \%)$ \\
\hline \hline
\end{tabular}

\section{Panel B}

For companies with a target capital structure:

What is your company's target amount of debt?

[expressed as a proportion of total (i.e. debt plus equity) finance]

\begin{tabular}{lcc} 
Target debt range & No of cos & $\mathbf{\%}$ of $\cos$ \\
$0 \%$ & 6 & 7 \\
$1-25 \%$ & 19 & 22 \\
$26-50 \%$ & 43 & 51 \\
$51-75 \%$ & 11 & 13 \\
$76-100 \%$ & 3 & 4 \\
$>100 \%$ & 3 & 4 \\
\cline { 2 - 3 } & \multicolumn{2}{c}{} \\
\cline { 2 - 3 } Mean (Median) & $45 \%$ & $(40 \%)$ \\
Minimum (Maximum) & $0 \%$ & $(300 \%)$
\end{tabular}

\section{Panel C}

Who/what is influential in setting target capital structure ratios?

Rank the following in order of importance (1 being most important, 9 being least important)

1 Company senior management

2 Existing shareholders

3 Commercial bankers

4 Investment bankers

5 Debt covenants

6 Outside investment analysts

7 Potential shareholders

8 Comparison with ratios of industry competitors

9 Major trade creditors

\begin{tabular}{|c|c|c|}
\hline \multicolumn{2}{|c|}{$(n=83)$} & \multirow[b]{2}{*}{ Grouping $^{2}$} \\
\hline $\begin{array}{l}\text { Mean } \\
\text { rank }^{1}\end{array}$ & $\begin{array}{l}\text { standard } \\
\text { deviation }\end{array}$ & \\
\hline 1.65 & 1.54 & 1 \\
\hline 4.10 & 2.23 & 2 \\
\hline 4.77 & 2.45 & 23 \\
\hline 5.06 & 2.61 & 34 \\
\hline 5.29 & 2.67 & 34 \\
\hline 5.70 & 2.41 & 4 \\
\hline 5.72 & 2.20 & 4 \\
\hline 6.37 & 2.23 & 5 \\
\hline 7.86 & 1.72 & 6 \\
\hline
\end{tabular}

\section{Notes}

1. Table is ordered by mean rank

2. Grouping based on statistical difference between rankings at 5\% (2-tail), using Wilcoxon-Mann-Whitney test 
Table 3: Ranking of long-term finance by companies that follow a hierarchy of finance sources

\begin{tabular}{|c|c|c|c|}
\hline \multirow[b]{2}{*}{ Source of long-term finance } & \multicolumn{2}{|c|}{$(n=112)$} & \multirow[b]{2}{*}{ Grouping $^{3}$} \\
\hline & $\begin{array}{c}\text { Mean } \\
\text { rank }^{1,2}\end{array}$ & $\begin{array}{l}\text { standard } \\
\text { deviation }\end{array}$ & \\
\hline 1 Internal reserves & 1.67 & 1.08 & 1 \\
\hline 2 Straight debt & 2.64 & 1.29 & 2 \\
\hline 3 Finance leases & 4.31 & 1.94 & 3 \\
\hline 4 Operating leases & 4.47 & 1.98 & 3 \\
\hline 5 Ordinary shares & 4.57 & 2.21 & 3 \\
\hline 6 Convertible debt & 5.98 & 1.78 & 4 \\
\hline 7 Straight preferred shares & 7.02 & 1.02 & 5 \\
\hline 8 Convertible preferred shares & 7.62 & 0.74 & 6 \\
\hline
\end{tabular}

Notes

1. Respondents ranked the eight sources from 1 (most favoured) to 8 (lease favoured)

2. Table is ordered by mean rank

3. Grouping based on statistical difference between rankings at 5\% (2-tail), using Wilcoxon-Mann-Whitney test 
Table 4: Cross-tabulation of number of companies adopting a target capital structure and those following a hierarchy

\begin{tabular}{lcc|c} 
& \multicolumn{2}{c|}{ Target } & \\
\cline { 2 - 3 } Hierarchy & Yes & No & Total \\
\cline { 2 - 3 } Yes & $61(32 \%)$ & $52(28 \%)$ & $113(60 \%)$ \\
No & $34(18 \%)$ & $42(22 \%)$ & $76(40 \%)$ \\
\cline { 2 - 3 } & $95(50 \%)$ & $94(50 \%)$ & $189(100 \%)$ \\
\hline \hline
\end{tabular}

Note

The null hypothesis of independence between 'target' and 'hierarchy' cannot be rejected $\left(\chi^{2}=1.55 ; p=0.213\right)$ 
Table 5: Spare borrowing capacity

Panel A: Policy

Yes No

Does your company have a policy for maintaining spare borrowing

capacity? $(\mathrm{n}=193)$

$59 \% \quad 41 \%$

Panel B: Amount

$\%$ of existing total long-term borrowing maintained as spare

$1-25 \%$

$26-50 \%$

$51-75 \%$

$76-100 \%$

\begin{tabular}{cc} 
No of $\cos$ & $\begin{array}{c}\% \text { of cos } \\
41\end{array}$ \\
$64 \%$ \\
17 & $27 \%$ \\
2 & $3 \%$ \\
4 & $6 \%$ \\
\hline 64 & $100 \%$ \\
\hline \hline
\end{tabular}

Mean (Median)

$29 \% \quad(20 \%)$

Minimum (Maximum)

$0 \% \quad(100 \%)$

Panel C: Source

For companies who maintain spare borrowing capacity $(n=114)$

$\begin{array}{lc}\text { Nature and source of spare borrowing capacity } & \mathbf{\%}^{\mathbf{1}} \\ \text { Overdraft facility } & 73 \\ \text { Unsecured loans } & 32 \\ \text { Leasing/hire purchase } & 21 \\ \text { Secured loans } & 20 \\ \text { Mortgage lending } & 4 \\ \text { Debentures } & 2 \\ \text { Other } & 12\end{array}$

Note

1. Percentages exceed $100 \%$ as respondents were asked to tick all applicable options Nature and source are shown in descending order of frequency

\section{Panel D: Reasons}

For companies who maintain spare borrowing capacity $(n=114)$

Reasons for spare borrowing capacity

Unplanned opportunities

$\%^{1}$

68

For acquisitions

54

Reserve for crisis

44

For special projects

31

Other

Notes

1. Percentages exceed $100 \%$ as respondents were asked to tick all applicable options

2. Reasons are shown in descending order of frequency 
Table 6: The relative importance of factors in choosing the appropriate amount of total debt

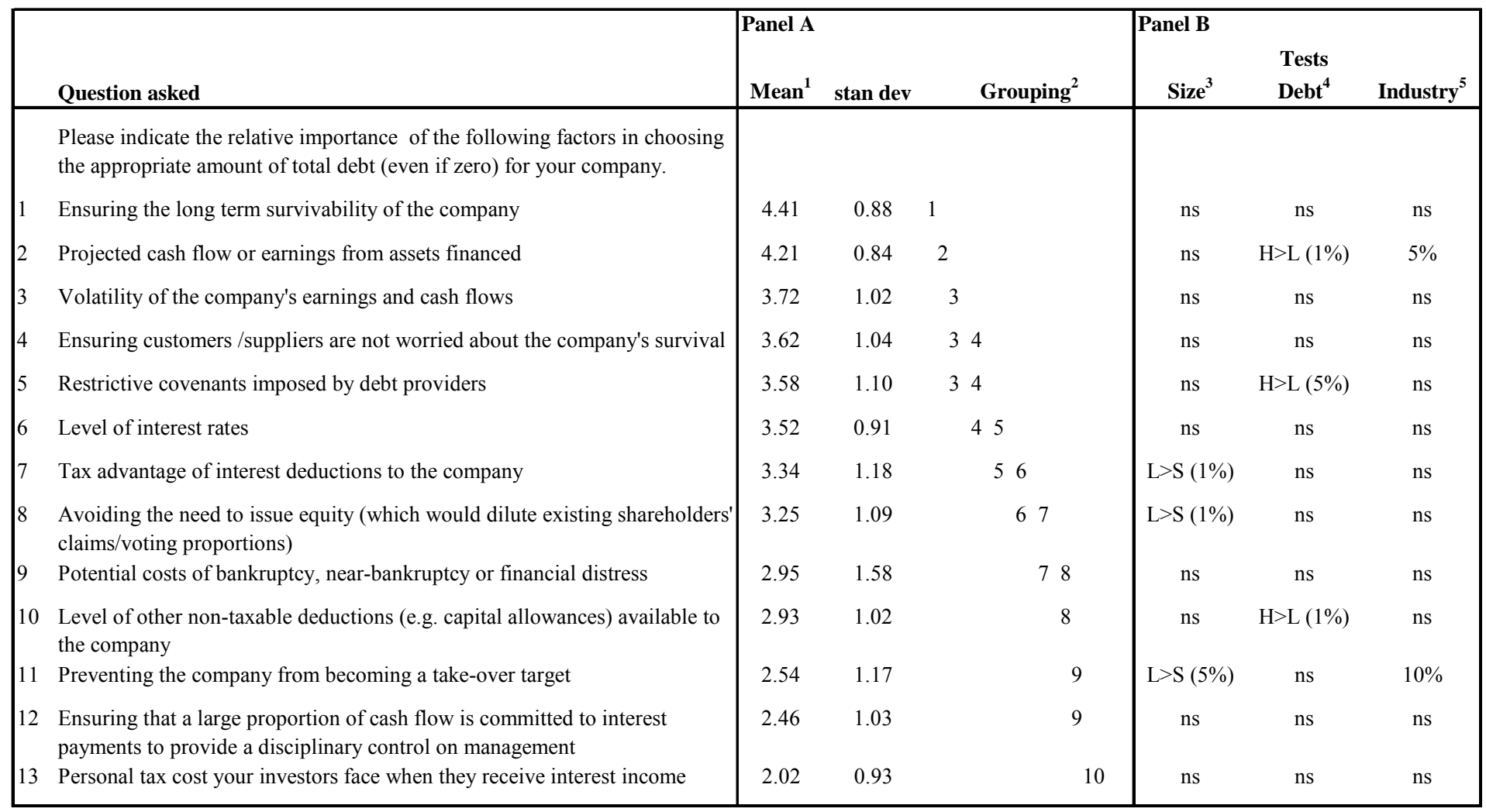

Notes

1. Response categories are: $1=$ not important at all; $2=$ of little importance; $3=$ fairly important; $4=$ =important; $5=$ =very important; table is ordered by mean response 2. Grouping based on statistical difference between rankings at 5\% (2-tail), using Wilcoxon-Mann-Whitney test

3. Significance level of Wilcoxon-Mann-Whitney 2-tail test for mean response difference between large (L) and small (S) companies;

Large/small companies represent top/bottom third of companies based on total assets. Mean(large) $>$ mean(small) in all cases

4. Significance level of Wilcoxon-Mann-Whitney 2-tail test for mean response difference between high (H) and low (L) geared companies

High/low geared represent top/bottom third of companies based on gearing measured as 'total debt/MV equity'. Mean(high geared) $>$ mean(low geared) in all cases

5. Significance level of Kruskal-Wallis test for mean response difference between industry groups

For row 2, Fisher's LSD tests suggest that responses from information technology (mean $=3.53$ ) and cyclical consumer goods (mean $=3.73)$ are sigificantly low

and from utilities (mean $=4.60)$, non-cyclical services $($ mean $=4.50)$ and resources $($ mean $=4.45)$ are significantly high.

For row 11, Fisher's LSD tests suggest that responses from resources $(\mathrm{mean}=1.91)$ and information technology $(\mathrm{mean}=1.93)$ are sigificantly low

and from non-cyclical services (mean $=3.33$ ) are significantly high. 


\section{Table 7: Views on general statements regarding capital structure determinants}

\begin{tabular}{|c|c|c|c|c|c|c|}
\hline & \multirow[b]{2}{*}{ Question asked } & \multicolumn{2}{|l|}{ Panel A } & \multicolumn{3}{|l|}{ Panel B } \\
\hline & & Mean $^{1,2}$ & stan dev & Size $^{3}$ & $\begin{array}{l}\text { Tests } \\
\text { Debt }^{4}\end{array}$ & Industry $^{5}$ \\
\hline & Please indicate the extent to which you agree with the following general statements in the context of UK liste & d companie & financ & lecisions. & & \\
\hline 1 & In making debt and equity decisions, a company considers the market response to new issues. & $4.20^{* * *}$ & 0.73 & $\mathrm{~ns}$ & ns & $\mathrm{ns}$ \\
\hline 2 & Use of debt would decrease relative to equity if bond interest were no longer tax deductible. & $3.79^{* * *}$ & 0.98 & ns & ns & ns \\
\hline 3 & A company would issue debt when equity is undervalued by the market. & $3.70^{* * *}$ & 0.97 & ns & $\mathrm{H}>\mathrm{L}(5 \%)$ & ns \\
\hline 4 & $\begin{array}{l}\text { If a company could issue unsecured long term debt at the same after-issue, after-tax cost of secured debt, it } \\
\text { would increase its use of debt financing. }\end{array}$ & $3.66^{* * *}$ & 0.91 & ns & ns & ns \\
\hline 5 & If a company were more dependent on $R \& D$ for its success, its debt to equity ratio would be lower. & $3.33^{* * *}$ & 1.13 & ns & ns & $5 \%$ \\
\hline 6 & $\begin{array}{l}\text { Private placements offer a satisfactory exchange of information between a company and investors without } \\
\text { publicising proprietary information in full. }\end{array}$ & $3.30^{* * *}$ & 0.94 & ns & ns & ns \\
\hline 7 & A decision to issue long term debt sends a favourable signal to the market about future long term prospects. & 3.10 & 0.86 & ns & ns & ns \\
\hline 8 & Restrictive covenants might be suggested in the hopes of convincing a doubtful lender to grant a loan. & 2.99 & 1.05 & ns & ns & ns \\
\hline 9 & $\begin{array}{l}\text { A company issues shares when prices are high, even though present needs are not great, in order to build up a } \\
\text { long term fund cushion. }\end{array}$ & 2.89 & 1.02 & ns & ns & ns \\
\hline 10 & $\begin{array}{l}\text { Issuing debt is delayed because of transaction costs and fees, and retiring debt is delayed because of } \\
\text { recapitalisation costs and fees. }\end{array}$ & 2.89 & 0.87 & ns & ns & ns \\
\hline 11 & The decision to issue debt or equity is affected by the existence of tax loss carry forwards. & $2.86^{* *}$ & 0.96 & $\mathrm{~ns}$ & ns & ns \\
\hline 12 & If bankruptcy occurred, finance directors would, in general, find comparable positions elsewhere. & $2.58^{* * *}$ & 1.06 & ns & ns & ns \\
\hline 13 & A company issues debt when recent profits are not sufficient to fund activities. & $2.56^{* * *}$ & 1.04 & ns & $\mathrm{H}>\mathrm{L}(5 \%)$ & ns \\
\hline 14 & Share price usually declines when debt is issued. & $2.40^{* * *}$ & 0.95 & $\mathrm{~S}>\mathrm{L}(5 \%)$ & ns & ns \\
\hline 15 & The present value of interest tax shields is balanced with the present value of possible bankruptcy costs. & $2.26^{* * *}$ & 0.83 & ns & ns & ns \\
\hline 16 & A company would issue shares to dilute the holdings of certain shareholders. & $2.18^{* * *}$ & 1.05 & ns & $\mathrm{ns}$ & $\mathrm{ns}$ \\
\hline 17 & A decision to issue shares sends an unfavourable signal to the market about future long-term prospects. & $2.07 * * *$ & 0.90 & ns & ns & ns \\
\hline
\end{tabular}

Notes

1. Response categories are: $1=$ strongly disagree; $2=$ disagree; $3=$ neutral; $4=$ agree; $5=$ strongly agree. Table is ordered by mean response

2. Significance of t-test of whether mean response is significantly different from $3=$ neutral; *** and $* *=$ significant at $1 \%$ and $5 \%$ levels, respectively (2-tail test)

3. Significance level of Wilcoxon-Mann-Whitney 2-tail test for mean response difference between large (L) and small (S) companies;

Large/small companies represent top/bottom third of companies based on total assets. Mean(large) $=2.24$; mean(small) $=2.61$ for the one difference (row 14)

4. Significance level of Wilcoxon-Mann-Whitney 2 -tail test for mean response difference between high $(\mathrm{H})$ and low $(\mathrm{L})$ geared companies

High/low geared represent top/bottom third of companies based on gearing measured as 'total debt/MV equity'.

Mean $($ high geared $)=3.81 ;$ mean $($ low geared $)=3.44$ for row $3 ;$ mean $($ high geared $)=2.77$; mean $($ low geared $)=2.31$ for row 13

5. Significance level of Kruskal-Wallis test for mean response difference between industry groups

For row 5, Fisher's LSD tests suggest that responses from utilities $($ mean $=2.33)$ are sigificantly low and from resources $($ mean $=4.30)$ are significantly high. 
Table 8: Summary of evidence on capital structure theory from present survey

\begin{tabular}{|c|c|c|c|c|c|c|}
\hline \multirow{3}{*}{ Theory and theory elements } & \multirow{3}{*}{$\begin{array}{l}\text { Table(row) or } \\
\text { text section }\end{array}$} & \multicolumn{5}{|c|}{ EVIDENCE } \\
\hline & & \multicolumn{2}{|c|}{ Against theory } & \multirow{2}{*}{ Neutral } & \multicolumn{2}{|c|}{ Supports theory } \\
\hline & & Strong & Weak & & Weak & Strong \\
\hline \multicolumn{7}{|l|}{ Traditional trade-off theory [1] } \\
\hline \multicolumn{7}{|l|}{ Direct evidence } \\
\hline Trade-off between interest tax shield and distress costs & $7(15)$ & $\mathrm{X}$ & & & & \\
\hline Target capital structure: strict/flexible & 2 (panel A) & & & & $\mathrm{X}$ & \\
\hline Reluctance to deviate from existing capital structure & text S4(iv) & & & & $\mathrm{X}$ & \\
\hline \multicolumn{7}{|l|}{ Interest tax shield [1A] } \\
\hline Interest rates & $6(6)$ & & & & $\mathrm{X}$ & \\
\hline Tax advantage of interest deductions & $6(7)$ & & & & $\mathrm{X}$ & \\
\hline Personal tax cost facing lenders & $6(13)$ & $\mathrm{X}$ & & & & \\
\hline Non-interest tax shields & $6(10)$ & & & $\mathrm{O}$ & & \\
\hline Tax advantage of interest deductions & $7(2)$ & & & & & $\mathrm{X}$ \\
\hline Debt/equity issue is affected by existence of tax loss carry forwards & $7(11)$ & & $\mathrm{X}$ & & & \\
\hline \multicolumn{7}{|l|}{ Financial distress [1B] } \\
\hline Potential costs of financial distress & $6(9)$ & & & $\mathrm{O}$ & & \\
\hline Ensuring long-term survivability & $6(1)$ & & & & & $\mathrm{X}$ \\
\hline Ensuring customers/suppliers not worried about co survival & $6(4)$ & & & & $\mathrm{X}$ & \\
\hline Volatility of earnings/cash flow & $6(3)$ & & & & $\mathrm{X}$ & \\
\hline High level of R\&D (increasing likelihood of financial distress) & $7(5)$ & & & & $\mathrm{X}$ & \\
\hline \multicolumn{7}{|l|}{ Extended trade-off theory [2] } \\
\hline \multicolumn{7}{|l|}{ Agency costs $[2 \mathrm{~A}]$} \\
\hline Restrictive covenants imposed by debt providers & $6(5)$ & & & & $\mathrm{X}$ & \\
\hline Collateral constraints on debt & $7(4)$ & & & & & $\mathrm{X}$ \\
\hline High level of R\&D (low level of tangible assets) & $7(5)$ & & & & $\mathrm{X}$ & \\
\hline \multicolumn{7}{|l|}{ Agency benefits [2B] } \\
\hline Interest as large part of cash flow to control management & $6(12)$ & $\mathrm{X}$ & & & & \\
\hline Restrictive covenants suggested to doubtful lenders & $7(8)$ & & & $\mathrm{O}$ & & \\
\hline Finance directors aware of personal costs of bankruptcy & $7(12)$ & & & & $\mathrm{X}$ & \\
\hline \multicolumn{7}{|l|}{ Pecking order theory [3] } \\
\hline \multicolumn{7}{|l|}{ Direct evidence } \\
\hline No target debt ratio & 2 (panel A) & & & & $\mathrm{X}$ & \\
\hline Willingness to deviate from existing capital structure & text S4(iv) & & & & $\mathrm{X}$ & \\
\hline Following a hierarchy of financial sources & text S4(iv) & & & & $\mathrm{X}$ & \\
\hline Internal resources most favoured & 3 & & & & $\mathrm{X}$ & \\
\hline Issuing debt when recent profits insufficient to fund activities & $7(13)$ & & $\mathrm{X}$ & & & \\
\hline Debt favoured over equity & 3 & & & & $\mathrm{X}$ & \\
\hline Use of debt avoids need to issue equity & $6(8)$ & & & $\mathrm{O}$ & & \\
\hline Volatility of earnings/cash flows & $6(3)$ & & & & $\mathrm{X}$ & \\
\hline Maintenance of financial slack & 5 (panel A) & & & & $\mathrm{X}$ & \\
\hline \multicolumn{7}{|l|}{ Underlying assumption of asymmetric information } \\
\hline Consideration of market response to debt/equity issues & $7(1)$ & & & & & $\mathrm{X}$ \\
\hline Private placements to avoid revealing proprietary info & $7(6)$ & & & & $\mathrm{X}$ & \\
\hline Decision to issue debt sends favourable signals & $7(7)$ & & & $\mathrm{O}$ & & \\
\hline Decision to issue shares sends unfavourable signals & $7(17)$ & $\mathrm{X}$ & & & & \\
\hline Belief that share price declines when debt is issued & $7(14)$ & & & & $\mathrm{X}$ & \\
\hline Issue debt when equity is undervalued & $7(3)$ & & & & & $\mathrm{X}$ \\
\hline Issue shares when prices high to build up fund cushion & $7(9)$ & & & $\mathrm{O}$ & & \\
\hline \multicolumn{7}{|l|}{ Corporate control [4] } \\
\hline Debt prevents co from becoming a takeover target & $6(11)$ & & $\mathrm{X}$ & & & \\
\hline Issue share to dilute certain equity holdings & $7(16)$ & $\mathrm{X}$ & & & & \\
\hline
\end{tabular}

